\title{
What Can We Learn From the 2010/11 Western Australian Marine Heatwave to Better Understand Risks From the One Forecast in 2020/21?
}

\author{
Brett W. Molony *, Damian P. Thomson and Ming Feng \\ Commonwealth Scientific Industrial Research Organisation (CSIRO) Oceans \& Atmosphere, Indian Ocean Marine Research \\ Centre, University of Western Australia, Perth, WA, Australia
}

Keywords: marine heatwave, Ningaloo Reef, Shark Bay (Australia), Ningaloo Niño, La Niña, coral bleaching

\section{INTRODUCTION}

In the austral summer of 2010/2011, the North West Shelf, Ningaloo Coast, and Shark Bay areas of Western Australia (WA) experienced a severe Marine Heatwave (MHW) event, with sea surface temperatures (SSTs) $>3^{\circ} \mathrm{C}$ higher than usual (Pearce et al., 2011; Pearce and Feng, 2013; Benthuysen et al., 2014), and up to $5^{\circ} \mathrm{C}$ higher off the mid-west coast (Pearce and Feng, 2013), which extended southwards along the Western Australian Coast (Hobday et al., 2016, 2018), with higher than average SSTs measurable along the southern coast of Australia (to $\sim 35^{\circ} \mathrm{S}$ ) (Kataoka et al., 2014; Tozuka et al., 2021) (Figure 1).

Edited by:

Dongyan Liu,

East China Normal University, China

The MHW event of 2010/11 was the most extreme (in intensity, extent and duration) reported at the time. The 2010/11 MHW event was a result of a strong Pacific La Niña, which forced high sea level anomalies that propagated through Indonesian Seas (via the Indonesian Throughflow)

Reviewed by:

Shuanglin Li,

Institute of Atmospheric Physics

(CAS), China

Zesheng Chen,

South China Sea Institute of

Oceanology (CAS), China

*Correspondence:

Brett W. Molony

brett.molony@csiro.au

Specialty section: This article was submitted to

Marine Ecosystem Ecology, a section of the journal

Frontiers in Marine Science

Received: 23 December 2020 Accepted: 04 February 2021

Published: 24 February 2021

Citation:

Molony BW, Thomson DP and Feng M (2021) What Can We Learn From the

2010/11 Western Australian Marine Heatwave to Better Understand Risks

From the One Forecast in 2020/21?

Front. Mar. Sci. 8:645383. to the northern WA coast. Coupled with local wind anomalies, the result was a much stronger than average southward-flowing Leeuwin Current (Pearce and Feng, 2013; Benthuysen et al., 2014; Tozuka et al., 2021), a not entirely unknown combination of climate and oceanographic processes and now referred to as the Ningaloo Niño (Kataoka et al., 2014; Tozuka et al., 2021). Higher than average temperatures during summer were also recorded for the following two summers (2011/12 and 2012/13) (Caputi et al., 2014) and thus impacts of higher than average summer SSTs for periods of several months were recorded over three consecutive summers (Babcock et al., 2020). In contrast, since 2013 the west coast of Australia has experienced a cold spell due to neutral or El Niño conditions (Feng et al., 2020), allowing many fishery stocks to recover, especially shortlived invertebrate species (crabs, scallops, and prawns) (Caputi et al., 2016; Hartill et al., 2019; Feng et al., 2020). The MHW event has resulted in increased concern among scientists, managers and the wider community about the frequency and impacts of these events on coastal marine ecosystems and people who depend on them for their livelihoods (Pecl et al., 2014; Wernberg et al., 2016; Harris et al., 2018; Hobday et al., 2018; Oliver et al., 2018, 2019; Pethybridge et al., 2020). A range of oceanographic products have since been developed to identify and classify MHW events (Pecl et al., 2014; Hobday et al., 2016, 2018), and to forecast risk, including the risks of coral bleaching events and tropical storms and cyclones [e.g., Bureau of Meteorology, Australia (BoM); National Oceanographic and Atmosphere Agency, USA (NOAA)].

The MHW event impacted a wide range of species, including habitat building species (corals, seagrasses, macroalgae, crustose coralline algae) (Wernberg et al., 2013, 2016; Short et al., 2015), fish and invertebrate species supporting commercial and recreational fisheries (Pearce et al., 2011; Caputi et al., 2014) and charismatic species of megafauna [e.g., whale sharks, manta rays (Pearce et al., 2011)]. Impacts included range contractions (Wernberg et al., 2016), expansions (Pearce et al., 2011; Lenanton et al., 2017) and localized extinctions [e.g., abalone, Lestang, \& Hart in 


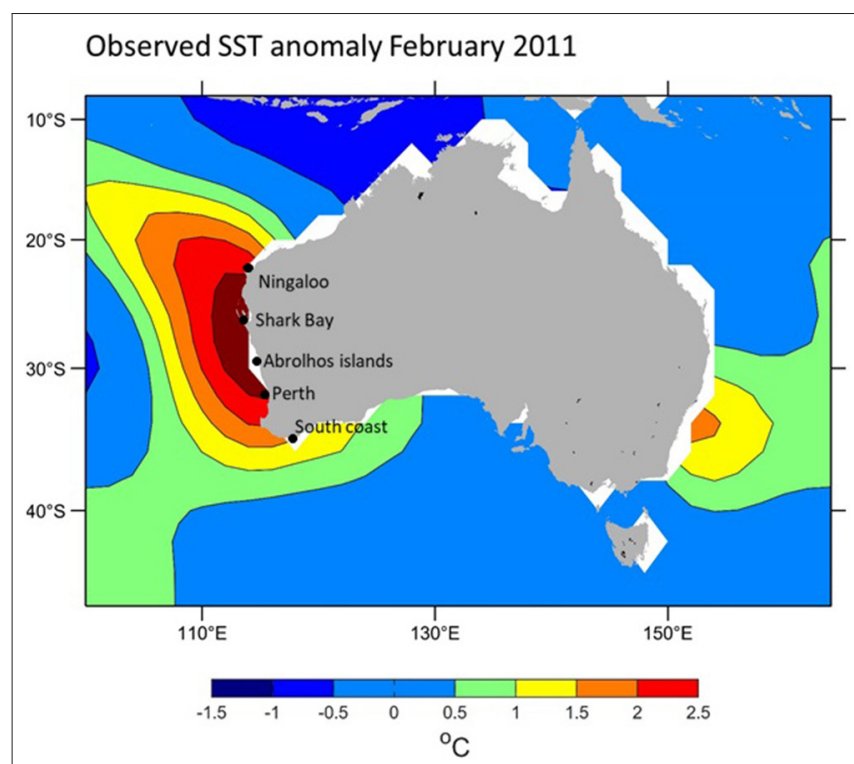

FIGURE 1 | Sea surface temperature anomalies in February 2011 at the peak of the 2010-2011 marine heatwave, derived from NOAA Extended Reconstructed SST version 5 (ERSSTv5) (Huang et al., 2017).

Pearce et al. (2011)]. Significantly, extensive losses of keystone species including seagrasses, kelps (Pearce et al., 2011; Caputi et al., 2014; Wernberg et al., 2016) and corals (Moore et al., 2012; Vanderklift et al., 2020) were reported. For example, the 2010/11 MHW resulted in a range reduction of more than $100 \mathrm{~km}$ in the important habitat forming species of kelp (Ecklona radiata) (Smale and Wernberg, 2013; Wernberg et al., 2013, 2016). There were also records of recruitment of tropical fishes into temperate areas (Lenanton et al., 2017) and sightings of typically tropical species including whale sharks (Pearce et al., 2011) and Spanish mackerel (Scomberomorus commerson) several $100 \mathrm{~km}$ further south than previously reported $\left(>35^{\circ} \mathrm{S}\right.$ Redmap, www.redmap.org.au).

Impacts to habitat-building species and associated species will flow through ecosystems to have other impacts (Wernberg et al., 2013). For example, mortalities of thousands of seabirds due to starvation were reported in the eastern Pacific after a MHW event (Piatt et al., 2020). Ecosystem impacts are likely to be more extreme in oligotrophic marine systems after MHW events due to the relatively low productivity (Molony et al., 2011), low standing biomasses and long-lived strategies characteristic of many marine fishes in these areas (Newman et al., 2018). These factors result in longer recovery times compared to more productive ecosystems.

MHW's can significantly impact coastal fisheries. For example, invertebrate fisheries (including saucer scallops, blue swimmer crabs, Roe's abalone) in Shark Bay and further southwards (e.g., Abrolhos Islands) were closed to commercial fishing for several years, as recruitment rates and adult biomasses declined, through direct (e.g., temperature effects) and indirect (loss of

Abbreviations: MHW, Marine Heatwave; SST, sea surface temperature; WA, Western Australia; GBR, Great Barrier Reef, Australia; WHA, World Heritage Area. seagrass habitat) effects of the MHW (Caputi et al., 2015b). Commercially and recreationally important marine fishes were also impacted via direct mortality (Pearce et al., 2011; Caputi et al., 2014, 2015a,b), as well as sublethal effects (e.g., reduced reproductive output and recruitment). Species such as pink snapper (Chrysophrys auratus) are known to have very restricted temperature ranges for successful spawning, which may have been exceeded by the MHW of 2010/11 (Caputi et al., 2015b). It remains uncertain if reductions in biomass and catches of pink snapper from the oceanic stock off Shark Bay (Gaughan and Santoro, 2020) are a direct, albeit long-term, result of the MHW of 2010/11 and the two subsequent summers of higherthan-average SSTs.

The ecosystem impacts were widespread over $1,000 \mathrm{~km}$ and also had economic effects. Fishers were impacted due to declines in fish abundance, recruitment rates (Caputi et al., 2016) and subsequent fishery closures (Caputi et al., 2014), and/or fishers moving in response to changes in fish distributions (Oliver et al., 2019). Management responses which significantly reduced fishing effort or closed fisheries for several years were applied (Caputi et al., 2016) to reduce or entirely remove fishing pressure to allow rebuilding of stocks. This impacted industries (commercial fishing, fishing tourism and regional, and cultural tourism), impacting local communities.

Regional communities were impacted beyond the MHW event of 2010/11, by floods (December 2010) and tropical storms (cyclone Lua, March 2012) [Tropical cyclone activity during 2010-11 and 2011-12 (bom.gov.au)] often associated with climatological events ( $L a$ Niña). The resulting reductions in regional tourism and accompanying economic activity compounded the livelihood impacts of the reduced or closed fisheries. Traditional owners were also impacted by changes in fish and marine fauna availability, distribution and abundance. Given that projected MHW days are to increase as a result of climate change (Wernberg et al., 2016; Oliver et al., 2018), there is concern that extreme MHW will also become more frequent.

National forecasting agencies have developed a range of forecasting tools around the risk and strengths of La Niña and El Niño events and their effects on coral bleaching risks and frequency of tropical storms. For example, the Australian BoM have predicted that a La Niña will peak in summer 20202021 [ENSO Outlook-an alert system for the El Niño-Southern Oscillation (bom.gov.au)], likely resulting in higher than average SSTs in north-west (Figure 2), and a stronger southward-flowing Leeuwin Current. These conditions are forecasted to be similar to those of 2010/11 [ENSO Outlook-an alert system for the El Niño-Southern Oscillation (bom.gov.au)]. The BoM also predicts that there is a high probability of coral bleaching along the mid to southwest coasts of WA, as well as for much of the Great Barrier Reef (GBR) and eastern side of Australia [Ocean Temperature Outlooks (bom.gov.au)]. In contrast, NOAA have predicted a lower and less extensive risk of coral bleaching from an ensemble of models, with much of the mid and southwest coasts of WA, and the GBR, being under low or no stress [90\% of ensemble models, NOAA Coral Reef Watch Coral Bleaching Heat Stress Outlook (CFS based) for the next 4 Months]. It will be an important task for the oceanography and 


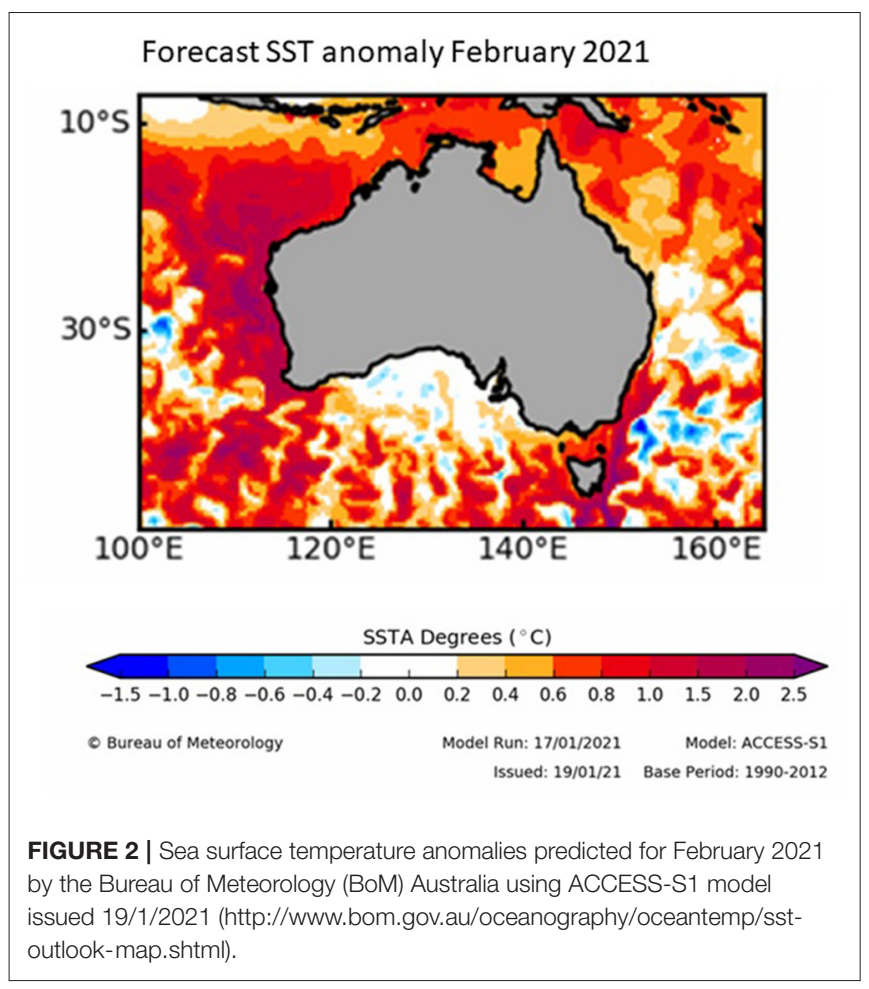

climate forecast communities to reconcile and improve regional prediction skills. These will ultimately rely on credible long-term ocean observations, both to monitor the marine environment and evaluate these model skills. Australia's Integrated Marine Observing System (IMOS) is poised to have moored and mobile (glider) platforms in place to capture the evolution of any 2020/21 MHW event (Feng et al., 2020; Holbrook et al., 2020).

\section{CONCLUSION}

Given the ecological, social and economic impacts of the 2010/11 MHW event, the likelihood of La Niña conditions for Australia in 2020/21 and the differences in coral bleaching and

\section{REFERENCES}

Babcock, R. C., Thomson, D. P., Haywood, M. D. E., Vanderklift, M. A., Pillans, R., Rochester, W. A., et al. (2020). Recurrent coral bleaching in NorthWestern Australia and associated declines in coral cover. Mar. Freshw. Res. doi: 10.1071/MF19378. [Epub ahead of print].

Benthuysen, J., Feng, M., and Zhong, L. (2014). Spatial patterns of warming off Western Australia during the 2011 Ningaloo Niño: quantifying impacts of remote and local forcing. Cont. Shelf Res. 91, 232-246. doi: 10.1016/j.csr.2014.09.014

Caputi, N., Feng, M., Pearce, A., Benthuysen, J., Denham, A., Hetzel, Y., et al. (2015a). Management Implications of Climate Change Effect on Fisheries in Western Australia, Part 1: Environmental Change and Risk Assessment. Fisheries Research Report No. 260. Western Australia: Department of Fisheries, 180. Available online at: http://www.fisheries.wa.gov.au/Documents/reserach reports/frr260.pdf other risks (e.g., number and intensity of cyclones) predicted, there are now several scientific opportunities. Firstly, given the experience in WA in 2010-2013 (and elsewhere at other times) can we identify and quantify the risks associated with the predicted La Niña events? Secondly, does this present an opportunity to test different regional climate forecasting models and further enhance their predictive abilities, including those associated with coral bleaching risk? These are critical questions as coral reefs are under threat from climate change and other risks globally (Parkinson et al., 2019), and these systems support livelihoods for tens of millions of people worldwide (Foale et al., 2013); can we better forecast the broader future scenarios of coral reefs and other marine habitat forming groups under a changing climate? Resourcing activities to address these questions will be critical to supporting ecological integrity, especially through human coupled systems. This in turn will assist in achieving the United Nation's Sustainability Development Goals (SDGs) in the United Nation's Decade of the Oceans.

\section{AUTHOR CONTRIBUTIONS}

$\mathrm{BM}$ and DT developed the initial concept of the paper. BM, $\mathrm{DT}$, and MF contributed to the writing, editing, and finalization of the manuscript. All authors contributed to the article and approved the submitted version.

\section{FUNDING}

This work was supported as part of the Ningaloo Outlook project. Ningaloo Outlook is a collaboration between CSIRO and BHP to increase our understanding of Ningaloo Reef. Together we are investing \$12.4 million over 10 years (2015-2025) to support research on whale sharks, turtles, shallow, and deepwater habitats.

\section{ACKNOWLEDGMENTS}

Many thanks to Edward King for an excellent review which increased the strength of this manuscript.

Caputi, N., Feng, M., Pearce, A., Benthuysen, J., Denham, A., Hetzel, Y., et al. (2015b). Management Implications of Climate Change Effect on Fisheries in Western Australia Part 2: Case Studies. Fisheries Research Report No. 261. Western Australia: Department of Fisheries, 156. Available online at: http:// www.fisheries.wa.gov.au/Documents/reserach_reports/frr261.pdf

Caputi, N., Jackson, G., and Pearce, A. (2014). The Marine Heat Wave Off Western Australia During the Summer of 2010/11 - 2 Years on. Fisheries Research Report No. 250. Western Australia: Department of Fisheries, 40. Available online at: http://www.fisheries.wa.gov.au/Documents/reserach_reports/frr250.pdf

Caputi, N., Kangas, M., Denham, A., Feng, M., Pearce, A., Hetzel, Y., et al. (2016). Management adaptation of invertebrate fisheries to an extreme marine heat wave event at a global warming hot spot. Ecol. Evol. 6, 3583-3593. doi: 10.1002/ece3.2137

Feng, M., Caputi, N., Chandrapavan, A., Chen, M., Hart, A., and Kangas, M. (2020). Multi-year marine cold-spells off the west coast of Australia and effects on fisheries. J. Mar. Syst. 214:103473. doi: 10.1016/j.jmarsys.2020.103473 
Foale, S., Adhuri, D., Aliño, P., Allison, E. H., Andrew, N., Cohen, P., et al. (2013). Food security and the coral triangle initiative. Mar. Policy 38, 174-183. doi: 10.1016/j.marpol.2012.05.033

Gaughan, D. J., and Santoro, K. (2020). Status Reports of the Fisheries and Aquatic Resources of Western Australia 2018/19: The State of the Fisheries. Perth, WA. Available online at: http://www.fish.wa.gov.au/Documents/sofar/status_ reports_of_the_fisheries_and_aquatic_resources_2018-19.pdf.

Harris, R. M. B., Beaumont, L. J., Vance, T. R., Tozer, C. R., Remenyi, T. A., Perkins-Kirkpatrick, S. E., et al. (2018). Biological responses to the press and pulse of climate trends and extreme events. Nat. Clim. Change 8, 579-587. doi: 10.1038/s41558-018-0187-9

Hartill, B. W., Taylor, S. M., Keller, K., and Weltersbach, M. S. (2019). Digital camera monitoring of recreational fishing effort: applications and challenges. Fish Fish. 21, 204-215. doi: 10.1111/faf.12413

Hobday, A. J., Alexander, L. V., Perkins, S. E., Smale, D. A., Straub, S. C., Oliver, E. C. J., et al. (2016). A hierarchical approach to defining marine heatwaves. Prog. Oceanogr. 141, 227-238. doi: 10.1016/j.pocean.2015.12.014

Hobday, A. J., Oliver, E. C. J., Gupta, A. S., Benthuysen, J. A., Burrows, M. T., Donat, M. G., et al. (2018). Categorizing and naming marine heatwaves. Oceanography 31, 162-173. doi: 10.5670/oceanog.2018.205

Holbrook, N. J., Sen Gupta, A., Oliver, E. C. J., Hobday, A. J., Benthuysen, J. A., Scannell, H. A., et al. (2020). Keeping pace with marine heatwaves. Nat. Rev. Earth Environ. 1, 482-493. doi: 10.1038/s43017-020-0068-4

Huang, B., Thorne, P. W., Banzon, V. F., Boyer, T., Chepurin, G., Lawrimore, J. H., et al. (2017). Extended reconstructed Sea surface temperature, Version 5 (ERSSTv5): upgrades, validations, and intercomparisons. J. Clim. 30, 8179-8205. doi: 10.1175/JCLI-D-16-0836.1

Kataoka, T., Tozuka, T., Behera, S., and Yamagata, T. (2014). On the Ningaloo Niño/Niña. Clim. Dyn. 43, 1463-1482. doi: 10.1007/s00382-0131961-z

Lenanton, R. C. J., Dowling, C. E., Smith, K. A., Fairclough, D. V., and Jackson, G. (2017). Potential influence of a marine heatwave on range extensions of tropical fishes in the eastern Indian Ocean-invaluable contributions from amateur observers. Reg. Stud. Mar. Sci. 13, 19-31. doi: 10.1016/j.rsma.2017.03.005

Molony, B. W., Newman, S. J., Joll, L., Lenanton, R. C. J., and Wise, B. (2011). Are Western Australian waters the least productive waters for finfish across two oceans? A review with a focus on finfish resources in the Kimberley region and North Coast Bioregion. J. R. Soc. West. Aust. 94, 323-332. Available online at: https://www.biodiversitylibrary.org/page/58039529.

Moore, J. A. Y., Bellchambers, L. M., Depczynski, M. R., Evans, R. D., Evans, S. N., Field, S. N., et al. (2012). Unprecedented mass bleaching and loss of coral across $12^{\circ}$ of latitude in Western Australia in 2010-11. PLoS ONE 7:e51807. doi: 10.1371/journal.pone.0051807

Newman, S. J., Brown, J. I., Fairclough, D. V., Wise, B. S., Bellchambers, L. M., Molony, B. W., et al. (2018). A risk assessment and prioritisation approach to the selection of indicator species for the assessment of multispecies, multi-gear, multi-sector fishery resources. Mar. Policy 88, 11-22. doi: 10.1016/j.marpol.2017.10.028

Oliver, E. C. J., Burrows, M. T., Donat, M. G., Sen Gupta, A., Alexander, L. V., Perkins-Kirkpatrick, S. E., et al. (2019). Projected marine heatwaves in the 21st century and the potential for ecological impact. Front. Mar. Sci. 6:734. doi: 10.3389/fmars.2019.00734

Oliver, E. C. J., Donat, M. G., Burrows, M. T., Moore, P. J., Smale, D. A., Alexander, L. V., et al. (2018). Longer and more frequent marine heatwaves over the past century. Nat. Commun. 9:1324. doi: 10.1038/s41467-01803732-9
Parkinson, J. E., Baker, A. C., Baums, I. B., Davies, S. W., Grottoli, A. G., Kitchen, S. A., et al. (2019). Molecular tools for coral reef restoration: beyond biomarker discovery. Conserv. Lett. 13:e12687. doi: 10.1111/conl.12687

Pearce, A. F., and Feng, M. (2013). The rise and fall of the "marine heat wave" off Western Australia during the summer of 2010/2011. J. Mar. Syst. 111-112, 139-156. doi: 10.1016/j.jmarsys.2012.10.009

Pearce, A. F., Lenanton, R., Jackson, G., Moore, J., Feng, M., and Gaughan, D. (2011). The "Marine Heat Wave" Off Western Australia During the Summer of 2010/11. Fisheries Research Report. 222. Western Australia: Department of Fisheries, 40. Available online at: http://www.fisheries.wa.gov.au/Documents/ reserach_reports/frr222.pdf

Pecl, G. T., Ward, T. M., Doubleday, Z. A., Clarke, S., Day, J., Dixon, C., et al. (2014). Rapid assessment of fisheries species sensitivity to climate change. Clim. Change 127, 505-520. doi: 10.1007/s10584-014-1284-Z

Pethybridge, H. R., Fulton, E. A., Hobday, A. J., Blanchard, J., Bulman, C. M., Butler, I. R., et al. (2020). Contrasting futures for Australia's fisheries stocks under IPCC RCP8.5 emissions - a multi-ecosystem model approach. Front. Mar. Sci. 7:577964. doi: 10.3389/fmars.2020.577964

Piatt, J. F., Parrish, J. K., Renner, H. M., Schoen, S. K., Jones, T., Arimitsu, M. L., et al. (2020). Extreme mortality and reproductive failure of common murres resulting from the northeast Pacific marine heatwave of 2014-2016. PLos ONE 15:e0226087. doi: 10.1371/journal.pone.0226087

Short, J., Foster, T., Falter, J., Kendrick, G. A., and McCulloch, M. T. (2015). Crustose coralline algal growth, calcification and mortality following a marine heatwave in Western Australia. Cont. Shelf Res. 106, 38-44. doi: 10.1016/j.csr.2015.07.003

Smale, D. A., and Wernberg, T. (2013). Extreme climatic event drives range contraction of a habitat-forming species. Proc. R. Soc. B Biol. Sci. 280:20122829. doi: 10.1098/rspb.2012.2829

Tozuka, T., Feng, M., Han, W., Kido, S., and Zhang, L. (2021). "The Ningaloo Niño / Niña: mechanisms, relation with other climate modes and impacts," in Tropical and Extratropical Air-Sea Interactions, ed S. K. Behera (Elsevier), 207-219. doi: 10.1016/B978-0-12-818156-0.00006-X

Vanderklift, M. A., Babcock, R. C., Barnes, P. B., Cresswell, A. K., Feng, M., Haywood, M. D. E., et al. (2020). The oceanography and marine ecology of Ningaloo, a world heritage area. Oceanogr. Mar. Biol. 58, 143-178. doi: 10.1201/9780429351495-4

Wernberg, T., Bennett, S., Babcock, R. C., De Bettignies, T., Cure, K., Depczynski, M., et al. (2016). Climate-driven regime shift of a temperate marine ecosystem. Science 353, 169-172. doi: 10.1126/science.aad8745

Wernberg, T., Smale, D. A., Tuya, F., Thomsen, M. S., Langlois, T. J., De Bettignies, T., et al. (2013). An extreme climatic event alters marine ecosystem structure in a global biodiversity hotspot. Nat. Clim. Change 3, 78-82. doi: $10.1038 /$ nclimate 1627

Conflict of Interest: The authors declare that the research was conducted in the absence of any commercial or financial relationships that could be construed as a potential conflict of interest.

Copyright (C) 2021 Molony, Thomson and Feng. This is an open-access article distributed under the terms of the Creative Commons Attribution License (CC BY). The use, distribution or reproduction in other forums is permitted, provided the original author(s) and the copyright owner(s) are credited and that the original publication in this journal is cited, in accordance with accepted academic practice. No use, distribution or reproduction is permitted which does not comply with these terms. 